\title{
THE USE OF AN INFORMATION SYSTEM TO MANAGE VOCATIONAL ASSESSMENT IN FACING THE 5.0 DIGITAL SOCIETY
}

\author{
I Made Sudana ${ }^{1}$, Syaad Pathmantara ${ }^{2}$, Dhega Febiharsa ${ }^{3}$, and Benti Gandisa ${ }^{4}$ \\ ${ }^{1}$ Department of Electrical Engineering Education, Universitas Negeri Semarang, Semarang, Indonesia \\ ${ }^{2}$ Department of Electrical Engineering, Universitas Negeri Malang, Malang, Indonesia \\ ${ }^{3}$ Department of System and Information Technology, Universitas Ivet, Semarang, Indonesia \\ ${ }^{4}$ Oromia Urban Development and Housing Bureau, Addis Ababa, Ethiopia, ${ }^{4}$ School of Economics and Management, \\ Beihang University, Beijing, China \\ E-mail: febiharsa@gmail.com
}

\begin{abstract}
Social distancing policy is applied during the Covid-19 virus pandemic including in Batik Professional Certification Institution in Indonesia. The management should provide services for the participants without meeting them directly. This study aims to reveal the management of Batik competence tests during the Covid-19 virus pandemic. The observation focused on the performance of the administrative staff, assessors, and management staff of the Batik Professional Certification Institutions (PCI). This is a qualitative study. The data were collected through questionnaires distributed to the participants, assessors, and administrators. The research concerns on the role and impact of the use of information system management in the interaction between prospective assessment, participants, assessors, and management of PCI in the professional certification competency test (PCCT). The findings showed that the use of information systems to manage vocational assessment has been effective to inform the assessment schedule to the assessor and participant, bridging the assessment reports, and reminding license expiration to management, so the management has an efficient way to manage the information with this system automation.
\end{abstract}

Keywords: assessment management, certification institution, information system, professional

\section{INTRODUCTION}

The assessment management in professional certification institutions requires the involvement of participants, assessors, and administrators/ management institutions. The information system is a bridge between the participants, assessors, and management. This study aims to unveil the impact of using web-based IS on the administrative process of competency testing on a PCI. The application of an IS that bridges the activities between stakeholders in PCI attract the researchers to observe, specifically dealing with the function, effectiveness, and usefulness of the system. The information system transformed human resources processes and practices mainly in terms of how organizations collect, store, use, and disseminate information [1]. Related to technical and database management systems, human resources information system development, are scattered throughout these criteria: (a) Data files should be integrated for easy cross-referencing among various departments and redundancy of data minimized; (b) Crucial data should be available on request (i.e. online), includes: the location of key employees, essential skills data, and promotion and performance information; (c) Appropriate variables for measurement (employee turnover, absenteeism, type of grievances, frequency of accidents, requests for transfers, and trends in personnel costs); (d) Quantifiable measures, which can include: attitudinal data correlated with demographics, performance 
and costs; (e) Standard and unplanned reports should be available on a timely basis, including immediate feedback on employee turnover, financial ratios and recruiting results; and (f) Advanced features, such as matching current personnel to future needs of an organization, succession planning, organizational change models and identification of prospective future managers and facilitation of their growth and development, which would enhance their performance [2].

The information system developed to help PCI management work efficiently to give online related data to the assessor, participant, and managers in the assessment process, from preparation, until assessment reporting. This digitization is for preparation for facing digital society 5.0 in future needs.

\section{METHOD}

This research is qualitative. The research concerns the role and impact of the use of IS management in the interaction between prospective assessment, participants, assessors, and management of PCI in the professional certification competency test (PCCT). The study was conducted in the batik PCI at Jalan Tambak Aji Raya No. 1 Tambak Aji, Ngaliyan District, Semarang City, Central Java Province, Indonesia. The data came from the questionnaires given to the participants, assessors, and administrators. Also, their researchers interviewed with the manager of Batik PCI.

The research followed these procedures of analysis, which are: (1) problem identification, (2) preparation of instruments; (3) validity and reliability tests for the instrument, (4) observation, questionnaires, and interviews, and (4) data analysis. Before the analysis, the researcher conducted a black-box test for the IS. According to Pressman [3], a black-box test is behavioral testing that focuses on software's functionality.

The sampling method follows Spradley's [4] social situation which covers the place, actor, and activities. In this case, there are three stakeholders for the objects of the research, which are three assessors, and three administrators, and one person for the management of Batik PCI. All of which is taken randomly. Afterward, we focused on the triangulation of data to compare the responses of the participants, assessors, and administrators. To support the process, we quoted the testimonies of the PCI stakeholders.

\section{RESULTS AND DISCUSSION}

The PCCT is carried out by the relevant Professional Certification Institution (PCI). According to BNSP [5], PCI is an agency for competence certification which is licensed by the Indonesian National Professional Certification Agency or BNSP. BNSP has the authority under the Government Regulation No. 23 of 2004 concerning the National Professional Certification Agency. In the Regulation, BNSP has the task of carrying out work competence certification [6]. Meanwhile, the institutions that have expertise authority, such as the PCCT in Indonesia are controlled by PCI. Ironically, there is still a limited number of PCCT institutions in Indonesia.

The IS management in PCCT provides better service. The system gives quick responses from email and SMS. The features help the PCI to send a broadcast message. According to Rand, et al. [7], SMS is useful in reminding and notifying information to participants. The use of SMS has a broader 
range, which is in line with the demands of the 5.0 digital society. In this era, every system should be fast and automated. The data integration of participants, assessors, assessment progress and other related data in the IS helps Batik's PCI service to provide fast information sending to registrants, participants, and assessors. As in Janssen \& Kuk [8], Innovation, improved efficiency of government services, by big data integration, improved effectiveness of government services. Apart of that, Skobelev \& Borovik [9] The key sciences and technologies that make possible a transition to Society 5.0 and that were briefly introduced in section 2 , are and will be in researchers' and ITdevelopers' focus in the nearest and distant future. According to Wilianto \& Fitri [10], Cloud Computing can reduce the network connection delay and CPU's usage.

The web-based IS supports the decision making in assessor management and determination; reporting on the number of assessments; scheduling; and the test locations. Based on the manager of certification responses, IS provides substantial benefits for PCI, because it is easier for PCI to obtain these data, which are: (1) applicants' certification; (2) participants' test history; (3) participants' certificate; and (4) certificate's expiration. Web-based IS used a dashboard to present the data. The dashboard makes the administrator easier to decide what action to do in the PCI management system. Besides, the dashboard also has the function to control and monitor the complexity of PCCT [11]. According to Kumar \& Prajapati [12], the major challenge for the interface designer, is the consolidation of all the information from different technologies and placing it on the dashboard in the best effective way, to sync the data from different technologies and to optimize the cognitive load of the dashboard.

Web-based software at Batik's PCI accommodates document administration needs until the pre-assessment and the selfevaluation process. Besides, the software aids online human resource management, mainly for the assessors and competence test participants. Hawking et al. [13], states that the application of the internet to Human Resources (HR) combines two elements: (1) the use of electronic media and (2) the active participation of employees in the process. These two elements drive technology that helps the organization reduces administrative costs, improves communication and employee satisfaction, provide real-time access to information, and reduces processing time. In the web-based PCI system, the employees are the administrative staff, assessors, and managers. IS in an organization or company combines human and technology to handle a set of business information. IS uses computer devices, databases, software, procedures, analytical models, and administrative decision-making processes [14]. The measurement of feasibility in this research follows Hornbæk [15]. He measures the effectiveness, efficiency, and user satisfaction of a system. Before the measurement's analysis, the researchers distributed questionnaires regarding the feasibility of IS to PCI to the experts, Batik's PCI personals. Next, the researchers obtained the data, as mentioned in Table 1. Based on the assessment, Batik PCI's information system has an average of very good ratings. In principle, the application has fulfilled the aspects of the use of a product. At a high level of usability, and in turn, is a good user experience, there will be some potential benefits that can be achieved. 
Table 1 . The Feasibility of the Information System

\begin{tabular}{|c|c|c|c|}
\hline \multirow[t]{2}{*}{ No } & \multirow[t]{2}{*}{ Aspect } & \multicolumn{2}{|c|}{$\begin{array}{l}\text { Administrator's } \\
\text { Respons }\end{array}$} \\
\hline & & 1 & 3 \\
\hline 1. & $\begin{array}{l}\text { The workflow of IS is easy } \\
\text { to understand }\end{array}$ & $\begin{array}{l}\text { Very } \\
\text { good }\end{array}$ & Good Good \\
\hline 2. & The IS is easy to operate & $\begin{array}{l}\text { Very } \\
\text { good }\end{array}$ & Good Good \\
\hline 3. & $\begin{array}{l}\text { The instructions in IS are } \\
\text { simple to follow }\end{array}$ & $\begin{array}{l}\text { Very } \\
\text { good }\end{array}$ & Good Good \\
\hline 4. & $\begin{array}{l}\text { The commands/ buttons/ } \\
\text { links in the IS application } \\
\text { are easy to understand }\end{array}$ & $\begin{array}{l}\text { Very } \\
\text { good }\end{array}$ & Good Good \\
\hline 5. & $\begin{array}{l}\text { Attractive appearance and } \\
\text { user-friendly (comfortable } \\
\text { to use) }\end{array}$ & $\begin{array}{l}\text { Very } \\
\text { good }\end{array}$ & Good Good \\
\hline 6. & $\begin{array}{l}\text { Selection of animation and } \\
\text { characters/ icons }\end{array}$ & $\begin{array}{l}\text { Very } \\
\text { good }\end{array}$ & Good Good \\
\hline 7. & $\begin{array}{l}\text { Using objects/icons that } \\
\text { correspond to the substance } \\
\text { of the material }\end{array}$ & $\begin{array}{l}\text { Very } \\
\text { good }\end{array}$ & Good Good \\
\hline 8. & $\begin{array}{l}\text { The objects (icon/ label/ } \\
\text { menu) are easy to } \\
\text { understand }\end{array}$ & $\begin{array}{l}\text { Very } \\
\text { good }\end{array}$ & Good Good \\
\hline 9. & $\begin{array}{l}\text { Attractive layout design } \\
\text { and easy to digest }\end{array}$ & $\begin{array}{l}\text { Very } \\
\text { good }\end{array}$ & $\begin{array}{l}\text { Pretty Very } \\
\text { Good good }\end{array}$ \\
\hline 10. & $\begin{array}{l}\text { The suitability of objects } \\
\text { and the effects of } \\
\text { transitions/ animations in } \\
\text { interesting }\end{array}$ & $\begin{array}{l}\text { Very } \\
\text { good }\end{array}$ & Good Good \\
\hline 11. & $\begin{array}{l}\text { The presentation of audio/ } \\
\text { video in a media program } \\
\text { can clarify the content }\end{array}$ & $\begin{array}{l}\text { Very } \\
\text { good }\end{array}$ & $\begin{array}{l}\text { PrettyGood } \\
\text { Good }\end{array}$ \\
\hline 12. & $\begin{array}{l}\text { The color composition is } \\
\text { balanced }\end{array}$ & $\begin{array}{l}\text { Very } \\
\text { good }\end{array}$ & Good Good \\
\hline 13. & Clarity of objects & $\begin{array}{l}\text { Very } \\
\text { good }\end{array}$ & Good Good \\
\hline 14. & IS is not boring & $\begin{array}{l}\text { Very } \\
\text { good }\end{array}$ & Good Good \\
\hline 15. & The materials in IS is clear & $\begin{array}{l}\text { Very } \\
\text { good }\end{array}$ & Good Good \\
\hline 16. & The IS has originality & $\begin{array}{l}\text { Very } \\
\text { good }\end{array}$ & $\begin{array}{l}\text { Very Good } \\
\text { good }\end{array}$ \\
\hline 17. & $\begin{array}{l}\text { The entire contents are } \\
\text { presented systematically } \\
\text { and densely }\end{array}$ & $\begin{array}{l}\text { Very } \\
\text { good }\end{array}$ & $\begin{array}{l}\text { PrettyGood } \\
\text { Good }\end{array}$ \\
\hline
\end{tabular}

According to Robbins \& Coulter [16], the efficacy of IS is interpreted by doing the right thing or completing activities so that a common goal is achieved. The IS is very useful for assessment, participants, assessors, and administrators of Batik PCI. The system helps in registering quickly and accurately. Besides, the system allows assessors in obtaining participant data and assessment documents. Also, the system helps the administrators to provide data rapidly and accurately within a shorter time.

The IS in the PCCT of Batik's PCI applies a computer-based assessment (CBA) system. According to Jawaid et al. [17], public perception of CBA is excellent, and they recommend its use for future assessments. In terms of quality, Piaw's [18] study believes that computer-based assessment can replace written test. His research shows that assessment participants who carry out Computer Based Test (CBT) and Paper Based Test (PBT) assessments are likely to produce the same score. Hence, the CBT test is valid in terms of test performance and potentially able to shift the use of PBT.

Boevé et al. [19] reinforce the use of CBA. He took a sample of psychology students at the University of Groningen in the Netherlands. He did not want to compare the two test models. However, the participants' scores obtained have similarities. Somehow, students have to practice and familiarize themselves with these computer-based test models.

Based on the observations to the assessors and participants in the competence test, it was found that some participants and assessors had a low literacy level of IT. To deal with the 4.0 industrial revolution, batik workers have to obtain digital literacy. Thus, there should be an improvement program of digital literacy for Batik workers (participants) and the assessors from PCI management to implement the IS. As in Noh [20], The indicator for digital literacy developed by the Korea Education and Research Information Service is roughly divided into technical/ environmental literacy, information/knowledge literacy, and social/ cultural literacy. The technical/ environmental literacy is divided into and 
evaluated by hardware, software, Internet, and digital resources. Information/ knowledge literacy is divided into and evaluated by information search and knowledge exploration, and social/cultural literacy is divided into and evaluated by social responsibility, laws, and ethics.

In the future, Video Conference (VC) assessment was needed to facing 5.0 digital society. To replace the physical, vocational assessment to digital assessment, the use of $\mathrm{VC}$ as media for skill assessment will have the opportunity to involve in the PCCT information system, so the assessor doesn't need to meet the participant face-to-face. Observation and interviews can be replaced by $\mathrm{VC}$ in the digital assessment process. Rahaeim, et. al. [21] As data from their workshop indicate, lack of knowledge about alternative solutions, and lack of digital skills constitute key barriers to change. One strategy, institutions may pursue in order to remedy the situation is to develop and implement an official assessment policy. Research about the uses of VC was done in reviewing condition, observation, examination, assess satisfaction, therapy and control, monitoring (person uses) and many other purposes with most $\mathrm{VC}$ types was Web-Based VC, through the internet [22].

\section{CONCLUSION}

The quality of IS services for PCI is assessed by both participants, assessors, and management of the PCI. This is stated from the assessment of the effectiveness, usefulness, and manageability of the use of IS for the PCCT. In this case, most stakeholders agree that IS is useful and very helpful in the process of competency testing. However, there is an urgency of increasing digital literacy, especially for users who are mostly elderly (over 40 years), senior assessors, and management teams who are clueless about IT technology. The implementation of a web-based IS can provide fast service to participants, assessors, and management in obtaining information related to PCCT. Therefore, it can assist in the selection of competence schemes, determination of human resources, and the decision making related to professional competence testing. The chance of digital assessment can be done with a video conference on the future process.

\section{REFERENCES}

[1] M. S. A. e Silva and C. G. da S. Lima, "The Role of Information Systems in Human Resource Management," Manag. Inf. Syst., 2018.

[2] E. Ankrah and S. Evans, "Human Resource Information System As a Strategic Tool in Human Resource Management," Probl. Manag. 21nd Century, vol. 5, 2012.

[3] R. S. Pressman, Software Engineering: A Practitioner's Approach 5th Edition. New York: The McGraw-Hill Companies, Inc., 2015.

[4] J. P. Spradley, Participant Observation. Holt: Rineheart and Winston, 1980.

[5] BNSP RI, Peraturan Badan Nasional Sertifikasi Profesi Nomor 5/BNSP/VII/2014 tentang Pedoman Persyaratan Umum Tempat Uji Kompetensi. Jakarta: Badan Nasional Sertifikasi Profesi RI, 2014.

[6] Sekretariat Kabinet RI, Peraturan Pemerintah Nomor 23 Tahun 2004 tentang Badan Nasional Sertifikasi Profesi. Jakarta: Sekretariat Kabinet RI, 2004.

[7] C. M. Rand, "Effectiveness of Centralized Text Message Reminders on Human Papillomavirus Immunization Coverage for Publicly 
Insured Adolescents," J. Adolesc. Heal., vol. 56, no. 5, 2018.

[8] M. Janssen and Kuk, "GBig and Open Linked Data (BOLD) in research, policy, and practice," $J$. Organ. Comput. Electron. Commer., vol. 26, no. 1-2, pp. 3-13, 2016.

[9] P. O. Skobelev and S. Y. Borovik, "On the Way from Industry 4.0 to Industry 5.0: From Digital Manufacturing to Digital Society," Int. Sci. J. "Industry 4.0," vol. II, no. 6, pp. 307-311, 2017.

[10] Wilianto and I. Fitri, "Information Technology Service Management with Cloud Computing Approach to Improve Administration System and Online Learning Performance," CommIT (Communication Inf. Technol. J., vol. 9, no. 2, pp. 51-57, 2015.

[11] T. A. Jordana and D. H. Suwarto, "Pemetaan Program Literasi Digital di Universitas Negeri Yogyakarta," Inf. Kaji. Ilmu Komun., vol. 47, no. 2, pp. 167-180, 2017.

[12] N. Kumar and S. Prajapati, "Challenges for Interface Designers in Designing Sensor Dashboards in the Context of Industry 4.0," Open Ind. Manuf. Eng. J., vol. 13, pp. 539542, 2019.

[13] P. Hawking, A. Stein, and S. Foster, "E-HR and Employee Self Service: A Case Study of a Victorian Public Sector Organisation," Issues Informing Sci. Inf. Technol., no. 1017-1026, 2004

[14] D. A. Almazan, "Influence of Information Systems on Organizational Result," Contaduría y Adm., vol. 62, no. 2, pp. 321-338, 2017.
[15] K. Hornbæk, "Current Practice in Measuring Usability: Challenges to Usability Studies and Research," Int. J. Human-Computer Stud., vol. 64, pp. 79-102, 2006.

[16] S. P. Robbins and M. Coulter, Management. San Francisco: Prentice Hall, 2012.

[17] M. Jawaid, F. A. Moosa, F. Jaleel, and A. J., "Computer-Based Assessment (CBA)," Percept. Resid. Dow Univ. Heal. Sci., vol. 30, no. 4, pp. 688-691, 2014.

[18] C. Y. Piaw, "Replacing Paper-Based Testing with Computer-Based Testing in Assessment: Are We Doing Wrong?," Procedia - Soc. Behav. Sci., vol. 64, no. 655-664, 2012.

[19] A. J. Boevé, M. R.R., A. C.J., B. Y., and B. R.J, "Introducing ComputerBased Testing in High-Stakes Exams in Higher Education: Results of a Field Experiment," PLoS One, vol. 10, no. 12, 2015.

[20] Y. Noh, "A Study on the Effect of Digital Literacy on Information Use Behavior," J. Librariansh. Inf. Sci., vol. 49, no. 1, pp. 26-56, 2017.

[21] A. Raaheim et al., "Digital Assessment - How Does It Challenge Local Practices and National Law? A Norwegian Case Study," Eur. J. High. Educ., vol. 9, no. 2, pp. 219-231, 2019.

[22] J. Mallow, T. Petitte, and G. Narsavage, "The Use of Video Conferencing for Persons with Chronic Conditions: A Systematic Review," Ehealth Telecommun Syst Netw, vol. 5, no. 2, pp. 39-56, 2016. 